\title{
Serum pepsinogen levels in gastric cancer patients and their relationship with Helicobacter pylori infection: a prospective study
}

\author{
Jimmy Bok-Yan So ${ }^{1}, \mathrm{Khay}$-Guan Yeoh $^{2}$, Shabbir Moochala ${ }^{3}$, Naresh Chachlani ${ }^{4}$, Jean $\mathrm{Ho}^{5}$, \\ Wai-Keong Wong ${ }^{6}$, Peter Mack ${ }^{6}$, and Peter M.-Y. GoH ${ }^{7}$ \\ ${ }^{1}$ Department of Surgery, National University Hospital, Lower Kent Ridge Road, Singapore 119072, Republic of Singapore \\ ${ }^{2}$ Department of Medicine, National University Hospital, Republic of Singapore \\ ${ }^{3}$ Defense Medical Research Institute, Republic of Singapore \\ ${ }^{4}$ Department of Pathology, National University Hospital, Republic of Singapore \\ ${ }^{5}$ Department of Pathology, Singapore General Hospital, Republic of Singapore \\ ${ }^{6}$ Department of Surgery, Singapore General Hospital, Republic of Singapore \\ ${ }^{7}$ Department of Surgery, University of Cologne, Germany
}

\begin{abstract}
Background. Our aim was to study the serum pepsinogen levels in gastric cancer patients in our population in relation to histology and the presence of Helicobacter pylori.

Methods. Forty-six patients with gastric cancer and 70 controls were studied prospectively in a 1-year period. Serum levels of pepsinogen I (PG I), pepsinogen II (PG II), and gastrin were measured by radioimmunoassay.

Results. The mean PG I levels for cancer patients and controls were $83.5 \mu \mathrm{g} / \mathrm{l}$ and $60.9 \mu \mathrm{g} / \mathrm{l}$, respectively $(P=0.03)$, the mean PG II levels were $27.2 \mu \mathrm{g} / \mathrm{l}$ and $12.1 \mu \mathrm{g} / \mathrm{l}$ respectively $(P<$ 0.0001). The PG I/II ratio was significantly lower in cancer patients $(P=0.04)$ and in those with Helicobacter infection. Serum pepsinogen levels were not affected by any pathological characteristics. Histology showed that the prevalence of chronic gastritis, intestinal metaplasia, and gastric atrophy was $97 \%, 56 \%$, and $15 \%$, respectively.

Conclusion. The prevalence of gastric atrophy is low in our population, and serum pepsinogen measurement is not useful as a screening tool for gastric cancer in this population.
\end{abstract}

Key words Pepsinogen · Gastrin · Gastric atrophy $\cdot H$. pylori . Gastric carcinoma

\section{Introduction}

Gastric cancer, despite a recent decline in its incidence, is still a leading cause of cancer death in the world. Results of treatment are often disappointing because most patients present late, a situation that occurs in Singapore and in most countries [1,2]. Early diagnosis can improve the outcome of gastric cancer, as this disease is curable in the early stages. Pepsinogen is a precursor of pepsin. The serum pepsinogen level reflects the secretory function of the gastric glands. Lev-

Offprint requests to: J.B.-Y. So

Received: July 8, 2002 / Accepted: September 2, 2002 els are decreased significantly in patients with chronic atrophic gastritis, an important precursor of gastric carcinoma [3-6]. It has been suggested that the measurement of serum pepsinogens can identify people at high risk for gastric cancer.

The use of serum pepsinogen measurement for gastric cancer screening has been described in Japan, with encouraging results [7-10]. However, because of potential ethnic, environmental, and disease differences, the use of serum pepsinogen screening requires local validation. Significant differences in serum pepsinogen levels were found between subjects in the Netherlands and Japan [11]. The aim of the present study was to study serum pepsinogen levels in control subjects and patients with gastric cancer in Singapore, with reference to histological features and Helicobacter pylori.

\section{Subjects and methods}

Specimens and data were collected prospectively from January to December 1998 from 46 patients with newly diagnosed gastric carcinoma and 70 control subjects with no endoscopic gastric abnormality. Patients were interviewed and blood samples were collected for assay. Control subjects were selected when they had no endoscopic abnormalities on evaluation for either dyspepsia or source of gastrointestinal bleeding. We excluded subjects under age 40 years, as age is a known factor affecting serum pepsinogen level, and gastric cancer is rare before age of 40 [7]. Patients with previous gastric surgery or any other treatment for stomach cancer, such as chemotherapy or radiotherapy, were excluded. Informed consent was obtained from all patients before the data was collected.

Serum samples were separated by centrifugation and individually stored at $-20^{\circ} \mathrm{C}$. Serum pepsinogens were 
measured by using pepsinogen I and II Riabead Kits (Dainabot, Tokyo, Japan), a modified radioimmunoassay method that had been described by Ichinose et al. [12] The serum sample was mixed with the pepsinogen antibody bead and the tracer ( ${ }^{125}$ I-labelled pepsinogen antibody). The reagents were agitated for $3 \mathrm{~h}$ at room temperature, and washed with distilled water. The radioactivity of the beads was then counted.

IgG antibodies to $H$. pylori in patient serum were detected using the HEL-pII Test kit (Amrad, Victoria, Australia). The HEL-pII Test kit utilizes the enzyme-linked immunosorbent assay (ELISA) technique for the detection of antibodies to $\mathrm{H}$. pylori. This ELISA kit has been evaluated in our laboratory on a series of local patients with known $H$. pylori histological status, with a demonstrated sensitivity of $90.2 \%$ and specificity of $83.3 \%$ [13]. Serum gastrin level was measured by radioimmunoassay, using the Gamma Dab [125I] Gastrin Radioimmunoassay Kit (DiaSorin, Stillwater, MN, USA). A pepsinogen (PG) I/II ratio of less than 2.5 was considered to be a biochemical marker of chronic gastritis, whereas a pepsinogen I level of less than $25 \mathrm{ng} / \mathrm{ml}$ was considered to indicate the presence of severe atrophy [14].

\section{Histological assessment of gastric cancer}

The gastrectomy specimens of gastric carcinoma were reviewed by two pathologists who were unaware of the other study results. Gastric adenocarcinoma was graded into well-, moderately, and poorly differentiated carcinoma. Histological gastritis was assessed in two random sections of nonmalignant gastric mucosa in the specimen. Chronic gastritis was diagnosed if there was an abundance of mononuclear cells in between the gastric glands. Gastric atrophy was diagnosed when there was a loss of gastric glands in the mucosa. Intestinal metaplasia was defined when the mucosa was replaced with intestinal-type epithelium.

\section{Statistics}

Serum pepsinogen I and II and gastrin levels were compared between the control subjects and gastric cancer patients. Association between the serum pepsinogen levels and other clinicopathological variables was evaluated with Student's $t$-test. The $\chi^{2}$ test was used to calculate the relative risk of cancer in patients with a very low PG I/II ratio. Correlation between the PG I/II ratio and serum gastrin level was assessed by Spearman's test.

\section{Results}

Forty-six patients with gastric cancer (median age, 66 years; range, 23-79 years) and 70 control subjects (median age, 55 years; range, 40-87 years) were studied. The male:female ratio was 31:15 in gastric cancer patients and 26:44 in controls. Thirty-four tumors (74\%) were poorly differentiated, and 12 were moderately differentiated carcinoma. Serum levels of pepsinogen I, pepsinogen II, and the PG I/II ratios in the cancer patients and controls are summarized in Table 1. Eightyone percent of subjects with gastric cancer and $62 \%$ of control subjects were $H$. pylori seropositive $(P=0.04)$. Overall, cancer patients had significantly higher levels of pepsinogen II and pepsinogen I than control subjects. The PG I/II ratio was significantly lower in cancer patients, as the increase in pepsinogen II was proportionally more than that in pepsinogen I. No difference in serum gastrin levels was found between the two groups. The serum pepsinogen I and pepsinogen II levels in cancer patients and controls in relation to $H$. pylori status are shown in Table 2. The other clinical or pathological variables had no effect on serum pepsinogen levels (Table 3)

Of the 46 patients with gastric cancer, 34 patients underwent gastric resection. Chronic gastritis was present in all but one (97\%) of the resected specimens. Intestinal metaplasia and gastric atrophy were present

Table 1. Mean serum pepsinogen (PG) I and II and gastrin levels in gastric cancer patients and normal subjects

\begin{tabular}{|c|c|c|c|c|c|c|}
\hline & \multicolumn{2}{|c|}{ Cancer patients } & \multirow[b]{2}{*}{$P^{*}$} & \multicolumn{2}{|c|}{ Normal subjects } & \multirow[b]{2}{*}{$P^{*}$} \\
\hline & $\begin{array}{c}\text { H. pylori } \\
\text { present }\end{array}$ & $\begin{array}{c}\text { H. pylori } \\
\text { absent }\end{array}$ & & $\begin{array}{c}\text { H. pylori } \\
\text { present }\end{array}$ & $\begin{array}{c}\text { H. pylori } \\
\text { absent }\end{array}$ & \\
\hline PG I ( $\mu \mathrm{g} / 1)$ & 82.5 & 87.9 & 0.8 & 58 & 65.5 & 0.5 \\
\hline PG II $(\mu \mathrm{g} / \mathrm{l})$ & 30.1 & 14.7 & 0.2 & 14.1 & 8.8 & 0.002 \\
\hline PG I/II ratio & 4.2 & 5.9 & 0.08 & 4.3 & 7.5 & $<0.0001$ \\
\hline Gastrin (pg/ml) & 100.9 & 130.2 & 0.06 & 93.7 & 59.3 & 0.2 \\
\hline
\end{tabular}

\footnotetext{
*Student's $t$-test
} 
Table 2. Mean serum pepsinogen I and II and gastrin levels according to H. pylori and cancer status

\begin{tabular}{|c|c|c|c|c|c|c|}
\hline & \multicolumn{2}{|c|}{$\begin{array}{l}\text { H. pylori-positive } \\
\text { subjects }\end{array}$} & \multirow[b]{2}{*}{$P^{\mathrm{a}}$} & \multicolumn{2}{|c|}{$\begin{array}{c}H . \text { pylori-negative } \\
\text { subjects }\end{array}$} & \multirow[b]{2}{*}{$P^{\mathrm{a}}$} \\
\hline & $\begin{array}{l}\text { Cancer } \\
(n=37)\end{array}$ & $\begin{array}{l}\text { Normal } \\
(n=43)\end{array}$ & & $\begin{array}{l}\text { Cancer } \\
(n=9)\end{array}$ & $\begin{array}{l}\text { Normal } \\
(n=27)\end{array}$ & \\
\hline PG I $(\mu \mathrm{g} / 1)$ & 82.5 & 58 & 0.04 & 87.9 & 65.5 & 0.06 \\
\hline PG II $(\mu \mathrm{g} / 1)$ & 30.1 & 14.1 & 0.005 & 14.6 & 8.8 & 0.02 \\
\hline PG I/II ratio & 4.1 & 4.3 & 0.7 & 5.9 & 7.5 & 0.9 \\
\hline Gastrin $(\mathrm{pg} / \mathrm{ml})$ & 100.9 & 97.2 & 0.9 & 130.2 & 59.6 & $<0.0001$ \\
\hline
\end{tabular}

Table 3. Association between pepsinogen levels and clinicopathological variables in gastric cancer patients

\begin{tabular}{|c|c|c|c|c|c|}
\hline & $n$ & $\begin{array}{c}\text { Pepsinogen I } \\
(\mu \mathrm{g} / \mathrm{l})\end{array}$ & $P$ & $\begin{array}{c}\text { Pepsinogen II } \\
(\mu g / 1)\end{array}$ & $P$ \\
\hline Male & 31 & 76.9 & & 23.2 & \\
\hline Female & 15 & 103 & 0.2 & 39.9 & 0.1 \\
\hline \multicolumn{6}{|l|}{ Location } \\
\hline Cardia & 12 & 80.6 & & 26.3 & \\
\hline Body & 8 & 139 & & 33.1 & \\
\hline Antrum & 26 & 81.2 & 0.15 & 20.3 & 0.3 \\
\hline \multicolumn{6}{|l|}{ Grade } \\
\hline Differentiated & 12 & 80.8 & & 28 & \\
\hline Poorly differentiated & 34 & 91.9 & 0.6 & 27.5 & 1.0 \\
\hline \multicolumn{6}{|l|}{ Nodes } \\
\hline Positive & 36 & 83.5 & & 20.8 & \\
\hline Negative & 8 & 102 & 0.5 & 28.7 & 0.3 \\
\hline \multicolumn{6}{|l|}{ Depth of invasion } \\
\hline Within wall & 8 & 108 & & 23 & \\
\hline Beyond wall & 36 & 81.1 & 0.3 & 22.6 & 1.0 \\
\hline \multicolumn{6}{|l|}{ Intestinal metaplasia } \\
\hline Present & 19 & 95.6 & & 24.2 & \\
\hline Absent & 15 & 112 & 0.5 & 30.4 & 0.5 \\
\hline \multicolumn{6}{|l|}{ Gastric atrophy } \\
\hline Present & 5 & 96.9 & & 14.8 & \\
\hline Absent & 29 & 104.1 & 0.9 & 29.0 & 0.007 \\
\hline \multicolumn{6}{|l|}{ History of ulcer } \\
\hline Present & 5 & 85.5 & & 20.7 & \\
\hline Absent & 31 & 86.1 & 1.0 & 22.6 & 0.8 \\
\hline \multicolumn{6}{|l|}{ Usage of PPI ${ }^{a}$} \\
\hline Yes & 6 & 106 & & 24.6 & \\
\hline No & 30 & 71.9 & 0.2 & 21.0 & 0.7 \\
\hline
\end{tabular}

in $56 \%$ and $15 \%$ of the specimens, respectively. Twelve $(26 \%)$ of the cancer patients had a PG I/II ratio of less than 2.5 , compared with $7 \%$ in the control subjects $(P=$ $0.006)$ Fifteen percent of those with cancer and $9 \%$ of controls had a pepsinogen I level of less than $25 \mathrm{ng} / \mathrm{ml}$ $(P=0.21)$. A serum PG I/II ratio of less than 2.5 was significantly associated with an increased risk of gastric cancer (relative risk, 4.6; $P=0.007$, Table 4). The positive and negative predictive values of a serum PG I/II ratio of less than 2.5 for gastric cancer were $71 \%$ and $65 \%$, respectively. Gastrin level was significantly higher
Table 4. Proportions of patients according to the serum pepsinogen ratio

PG I/II Cancer subjects Normal subjects Gastrin level $\begin{array}{llll}\text { ratio } & (\%) & (\%) & (\mathrm{pg} / \mathrm{ml})\end{array}$

\begin{tabular}{lcrr}
\hline$<2.5$ & $12(26)$ & $5(7)$ & $179.1^{* *}$ \\
$>2.5^{*}$ & $34(74)$ & $65(93)$ & $76.6^{* *}$
\end{tabular}

* Relative risk, 4.6; $P=0.007, \chi^{2}$ test; ** $p<0.001$, Student's $t$-test 
in patients with a serum PG I/II ratio of less than 2.5. There was a significant negative correlation between serum gastrin level and PG I/II ratio ratio (Spearman's correlation coeficient, $-0.28 ; P=0.002)$.

\section{Discussion}

Two biochemically distinct pepsinogens are produced by gastric mucosa. Pepsinogen I is produced primarily by fundic mucosa, whereas pepsinogen II is secreted by fundic, antral, and duodenal mucosa. Levels of both serum pepsinogens and of serum gastrin have been shown to be accurate functional markers of the state of the gastric mucosa $[3,4]$. The serum pepsinogen I level and the PG I/II ratio were low in chronic atrophic gastritis. Chronic atrophic gastritis is believed to be an important premalignant condition for the development of gastric carcinoma, particularly the intestinal type [5]. The serum PG I/II ratio is also reduced in gastric carcinoma, as pepsinogen I decreases proportionally more than pepsinogen II. In contrast, the serum level of gastrin is increased in atrophic corpus gastritis [15].

In Japan, where studies have shown a high prevalence of chronic gastritis, serum pepsinogen has been studied as a mass screening tool for the detection of gastric cancer [7-10]. Screening by using serum pepsinogen has advantages over other methods such as endoscopy and barium studies. It is simple and inexpensive, and there is no radiation hazard. Early studies from Japan have shown that the serum pepsinogen I level was significantly lower in gastric cancer patients than in normal controls $[8,16]$. In contrast, no difference was found in serum pepsinogen II levels between the two groups. Hence, the PG I/II ratio was lower in gastric cancer patients. Various cutoff values for screening have been proposed; typically, serum pepsinogen I less than $70 \mu \mathrm{g} /$ 1 and a PG I/II ratio of less than 3 are used for screening. The sensitivity and specificity ranged from $55 \%$ to $84.6 \%$ and $73.5 \%$ to $78.9 \%$, respectively [7-10].

Our results were quite different from the Japanese data. In our study, both pepsinogen I and pepsinogen II were significantly higher in gastric cancer patients than in the control subjects. The increase in pepsinogen II levels was greater than that in pepsinogen I, so there was still a decrease in the PG I/II ratio in cancer patients. In this study, we employed the same radioimmunoassay technique to measure serum pepsinogen as in the original description [12]. A standard curve was constructed before the actual measurement was performed, and all the tests were repeated twice to confirm the readings. There may be several reasons for the difference in the the two populations. First, there is a difference in prevalence of gastric atrophy. In our study, only a minority of our gastric cancer patients had evidence of gastric atrophy by both biochemical and histological assessments. In this study, the measured PG I/II ratio correlated well with the serum gastrin measurement. Our findings are also consistent with a previous report from our hospital, in which only $22 \%$ of gastric cancer specimens showed evidence of atrophic gastritis in the gastric body [17]. In Japan, however, over $90 \%$ of gastric cancer patients have evidence of atrophic gastritis [18]. It is well known that there is a wide geographic difference in serum pepsinogen levels and in the prevalence of gastric atrophy [11,19]. Gastric atrophy has a stronger association with intestinal-type than with diffuse-type gastric carcinoma [5,19]. In our study, most of the cancers were poorly differentiated. Our data indicate that a significant percentage of gastric cancers in our population develop without the presence of gastric atrophy. We conclude that the latter is therefore not an essential intermediate step in gastric carcinogenesis.

Another possible explanation for the differences between our findings and the Japanese data may be related to the presence of $H$. pylori. Eighty-one percent of our gastric cancer patients were seropositive for $H$. pylori, compared with $62 \%$ of the controls. H. pylori infection is known to be associated with a raised serum pepsinogen II level and a decreased PG I/II ratio [20,21]. Furthermore the majority of $H$. pylori strains in our population express cytotoxin-associated gene A (cagA) $[22,23]$, which is known to be associated with more active mucosal inflammation and, hence, higher levels of serum pepsinogen I and II than other strains [24].

In conclusion, compared with the findings in our controls, our study showed an increase in serum PG I and II levels and a lower PG I/II ratio in our gastric cancer patients. Gastric atrophy was present in a small proportion of patients with gastric cancer and may not be an essential stage in gastric carcinogenesis. Serum pepsinogen measurement is not useful for the screening of gastric cancer in our population.

\section{References}

1. Ti TK. Pattern and surgical treatment of gastric cancer in Singapore. Br J Surg 1993;80:886-9.

2. Wanebo HJ, Kennedy BJ, Chmiel J, Steele G, Winchester D, Osteen R. Cancer of stomach. A patient care study by the American College of Surgeons. Ann Surg 1993;218:583-592.

3. Samloff IM, Varis K, Ihamaki T, Siurala M, Rotter JL. Relationships among serum pepsinogen I, serum pepsinogen II, and gastric mucosal histology - a study in relatives of patients with pernicious anemia. Gastroenterology 1982;83:204-9.

4. Miki K, Ichinose M, Shimizu, Huang SC, Oka H, Furihata C, et al. Serum pepsinogens as a screening test of extensive chronic gastritis. Gastroenterol Jpn 1987;22:133-141.

5. Correa P. Human gastric carcinogenesis: a multistep and multifactorial process. Cancer Res 1992;52:6735-40

6. Fukao A, Hisamichi S, Ohsato N, Fujino N, Endo N, Masaharu I. Correlation between the prevalence of gastritis and gastric cancer in Japan. Cancer Causes Control 1993;4:17-20 
7. Miki K, Ichinose M, Ishikawa K, Yahagi N, Matsushima M, Kakei $\mathrm{N}$, et al. Clinical application of serum pepsinogen I and II levels for mass screening to detect gastric cancer. Jpn J Cancer Res 1993; 84:1086-90.

8. Kudoi A, Yoshihara M, Sumii K, Huruma K, Kajiyama G. Serum pepsinogen in screening for gastric cancer. J Gastroenterol 1990; 30:452-60.

9. Yoshihara M, Sumii K, Haruma K, Kiyohira K, Hattori N, Kitadai $\mathrm{Y}$, et al. Correlation of ratio of serum pepsinogen I and II with prevalence of gastric cancer and adenoma in Japanese subjects. Am J Gastroenterol 1998;7:1090-6.

10. Kitahara F, Kobayashi K, Sato T, Kojima Y, Araki T, Fujino MA. Accuracy of screening for gastric cancer using serum pepsinogen concentrations. Gut 1999;44:693-7.

11. Schlemper RJ, van der Werf SDJ, Vandenbroucke JP, Birmond I, Lamers C. Seroepidemiology of gastritis in Japanese and Dutch working populations: evidence for the development of atrophic gastritis that is not related to Helicobacter pylori. Gut 1995;37: 199-204.

12. Ichinose M, Miki K, Furihata C, Kageyama T, Hayashi R, Niwa H et al. Radioimmunoassay of serum group I and II pepsinogens in normal controls and patients with various disorders. Clin Chim Acta 1982;126:183-91

13. Kang JY, Yeoh KG, Ho KY, Lim TP, Quak SH, Wee A, et al. Racial differences in Helicobacter pylori seroprevalence in Singapore: correlation with differences in peptic ulcer frequency. J Gastroenterol Hepatol 1982;12:655-99.

14. Hengals KJ. Das Menschliche pepsinogen-pepsin system. Stuttgart: Georg Thieme Verlag; 1986.

15. Westerveld BD, Pals G, Lamers CBHW, Defize J, Pronk JC, Frants RR. Clinical significance of pepsinogen A isozymogens, serum pepsinogen $\mathrm{A}$ and $\mathrm{C}$ levels, and serum gastrin levels. Cancer 1987;59:952-8.
16. Miki K, Ichinose M, Kawamura N, Matsushima T, Ahmad HB, Kimura M, et al. Serum pepsinogen levels to detect gastric cancer associated with chronic gastritis in Japanese subjects. Jpn J Cancer Res 1989;80:111-4.

17. Wee A, Kang KY, Teh M. Helicobactor pylori and gastric cancer: correlation with gastritis; intestinal metaplasia, and tumour histology. Gut 1992;33:1029-32.

18. Kato I, Tominaga S, Ito Y, Kobayashi S, Yoshii Y, Matsuura A, et al. Atrophic gastritis and gastric cancer risk: cross section analysis. Jpn J Cancer Res 1992;83:1041-6.

19. Kuipers EJ. Relationship between Helicobactor pylori, atrophic gastritis and gastric cancer. Aliment Pharmacol Ther 1998;12 (Suppl 1):25-36.

20. Asaka M, Kimura T, Kudo M, Takeda H, Mitani S, Miyazaki T, et al. Relationship of Helicobactor pylori to serum pepsinogens in an asymptomatic Japanese population. Gastroenterology 1998;102: $760-6$.

21. Webb PM, Hengels KJ, Moller H, Ninewell DG, Palli D, Elder $\mathrm{JB}$, et al. The epidemiology of lower serum pepsinogen A levels and an international association with gastric cancer rates. Gastroenterology 1994;107:1335-44.

22. Zheng PY, Hua J, Yeoh KG, Ng HC, Ho B. Association of peptic ulcer with increased expression of Lewis antigens, but not cagA, ice $\mathrm{A}$ and vacA in Helicobactor pylori isolates in an Asian population. Gut 47:18-22, 2000

23. Huan J, Zheng PY, Yeoh KG, Ho B. The enigmatic prevalence of cagA positive Helicobacter pylori in Singapore. Microbios 2000; 102:113-20

24. Webb PM, Crabtree JE, Forman D. Gastric cancer, cytotoxinassociated gene A-positive Helicobacter pylori, and serum pepsinogens: an international study. Gastroenterology 1999;116: $269-76$. 